\title{
Utilization of Gasoline Fuel as an Alternative Fuel for LPG Substitution
}

\author{
Asril Mallombasang ${ }^{\mathrm{a}}$, Zuryati Djafar ${ }^{\mathrm{b}, *}$, Wahyu Haryadi Piarah ${ }^{\mathrm{c}}$ \\ ${ }^{\text {a}}$ Department of Mechanical Engineering, Faculty of Engineering, Universitas Hasanuddin. Email: mallombasangchito@ gmail.com \\ ${ }^{b}$ Department of Mechanical Engineering, Faculty of Engineering, Universitas Hasanuddin. Email: zuryatidjafar@unhas.ac.id \\ 'Department of Mechanical Engineering, Faculty of Engineering, Universitas Hasanuddin. Email: wahyupiarah@unhas.ac.id
}

\begin{abstract}
The subsidized gasoline conversion to LPG $3 \mathrm{~kg}$ in 2007 became the Indonesian Government's policy to reduce reliance on fuel oil. The increasing LPG consumption and obstacle distribution have been the scarcity of the LPG in all regions of Indonesia. The gasoline fuel stove has overcome from the LPG scarcity. So, this research has conducted by comparing the consume rate between both Pertalite and Pertamax of gasoline types to fuel LPG at the boiling process 1 litre of water which has used the quantum gas stove, with several pressure variations from $1.5 \mathrm{kPa}$ to $2.5 \mathrm{kPa}$. Test results showed that the highest fire temperatures for Pertalite $430{ }^{\circ} \mathrm{C}$ fuel, Pertamax $530{ }^{\circ} \mathrm{C}$ fuel and LPG $578{ }^{\circ} \mathrm{C}$ fuel. Fuel consumption for Pertalite $0.025 \mathrm{~kg}$, Pertamax $0.027 \mathrm{~kg}$ and LPG $0.061 \mathrm{~kg}$. While the distribution time is $682 \mathrm{~s}$ for Pertalite, $669 \mathrm{~s}$ Pertamax and $503 \mathrm{~s}$ for LPG. The least compaction efficiency value occurs at $1.5 \mathrm{kPa}$ pressure, for Pertalite $6.136 \%$, Pertamax $7.730 \%$ and LPG $9.018 \%$. The higher the pressure hence greater the fuel efficiency, instead the fuel consumption and water boiling time are reduced. The cost used to boil water on Pertalite is 236 Rupiah, Pertamax 251 Rupiah, and LPG is 309 Rupiah.
\end{abstract}

Keywords: Air pump; efficiency; pertalite; stove; tube reactor

\section{Introduction}

Indonesia is one of the countries which have abundant natural resources like petroleum. Natural resources have been processed and used in supporting daily activity such as industrial field, transportation, household but the main problem of petroleum resources is scarcity. Indonesian's Government has exhibited the issue policy to replace kerosene usage to LPG gas. The purpose of this policy is reducing consume rate of kerosene continuously [1].

LPG gas is a fuel taken from natural gas contained in the earth and processed into gas that can be used by the community as an innovation in the utilization of natural resources in Indonesia.

If the kerosene conversion to LPG gas is a success, the Indonesian Government is saving 15 to 20 trillion fuel oil subsidized every year [2]. The target of conversion of kerosene to LPG gas is to households and microenterprises. For household criteria that get it is a user of pure kerosene, does not have an LPG stove, earns less than 1.5 million every month and is a native of the area. While the criteria of micro-enterprises are consuming kerosene to production process [3].

The role of fuel oil (BBM) in this modern era is usefully significant that almost all activity has been using

\footnotetext{
*Corresponding author. Telp. +62-812-8047-7465

Jalan Poros Malino km. 6, Bontomarannu,

Gowa, South Sulawesi, Indonesia 92171
}

fuel oil. This energy source has been used as long as thousands of years due to its flexible nature. As a simple example of using BBM in daily life is the use of an oil stove for cooking. Of course, we remember the government's efforts to replace kerosene stoves with gas stoves on the grounds of increasing efficiency. Some cases of fire that occur in Indonesia has caused by gas stoves because of the very flammable fuel of the LPG. When LPG gas became scarce, some of people returned to using kerosene and even firewood, but some also tried gasoline as an alternative to LPG gas.

Alkarim, et al., [4] in their research using a reactor tube containing Pertalite connected to an aerator (air pump) as an air supply as well as a Pertalite evaporation aid. So, Ridhuan and Darma [5] used a stove with premium fuel, This is to determine the variation in the number of holes and the diameter of the stove burner on premium fuel consumption. Another related research has been revealed by Sukandi and Porawati [6] that has used a reactor tube as a storage container of hydrogen gas as stove fuel.

\section{Fundamental Theory}

\subsection{Pertalite fuel}

Pertalite is an oil fuel issued by Pertamina company with Research Octane Number (RON) 90, an announcement in May 2015, and green bright in color characteristics [7]. The rule of the mixture used for 
manufacturing Pertalite is Naphtha where has RON 65 70. Enhance the quality of RON becomes RON 90 can be conducted by mixed with High Octane Mogas Component (HOMC), and EcoSAVE additives have also added to make the engine smoother, cleaner, and more efficient [8].

\subsection{Pertamax fuel}

Pertamax was first launched in 1999 to replace the premium mixture (premix 98) because it contains Methyl Tertiary Butyl Ether (MTBE) compound that is not environment friendly. Pertamax is a recommendation for vehicles produced after 1990, especially those that have used technology equivalent to electronic fuel injection (EFI) and catalytic converters (catalytic converters). Pertamax is produced by Pertamina base on the decision of the Directorate General of Oil and Gas No. 3674/K24/DJM/2006, dated 17 March 2006 concerning specifications for gasoline, 91 [9].

\subsection{LPG (Liquified Petroleum Gases)}

LPG stands for Liquified Petroleum Gas, which means gas that is liquefied at any pressure and has obtained from fractionated petroleum. The types of LPG based on its specifications have mixed LPG, propane LPG and butane LPG. Whereas currently circulating in the community based on the Decree of the DirectorGeneral of Oil and Gas Number: 25K/36/DDJM/1990 is a type of mixed LPG. To reduce the risk of explosion and find out the gas leak in the tube, Pertamina has added mercaptan gas that has a distinctive odor and has nose piercing properties [10].

\subsection{Calorific value}

The heating value is a property of a fuel which states the energy magnitude of the fuel. Determination of the calorific value of the fuel can be done by testing or by estimating based on the raw components of the fuel [11]. Meanwhile, low heating value (LHV) is the heating value where it has assumed that water and hydrogen are in the vapor phase [12]. The calorific value, density and fuel price of Pertalite, Pertamax and LPG can be seen in Table 1.

\subsection{Maturity Efficiency}

Maturity efficiency is the ratio between the useful heat needed to heat water a certain amount from the initial temperature until mature with the heat provided by the fuel [15].

The method used is to boil 1 (one) liter of water to a temperature between $95^{\circ} \mathrm{C}$ to $99^{\circ} \mathrm{C}$ on the one eye stove using gasoline types Pertalite, Pertamax, and $3 \mathrm{~kg}$ LPG

Table 1. Calorific value (LHV), density and price of fuels [9], [13], [14]

\begin{tabular}{cccc}
\hline $\begin{array}{c}\text { Type of } \\
\text { fuel }\end{array}$ & $\begin{array}{c}\text { Calorific value }(\mathbf{L H V}) \\
(\mathbf{k J} / \mathbf{k g})\end{array}$ & $\begin{array}{c}\text { Density } \\
\left(\mathbf{k g} / \mathbf{m}^{\mathbf{3}}\right)\end{array}$ & $\begin{array}{c}\text { Price } \\
(\mathbf{R p} .)\end{array}$ \\
\hline Pertalite & 44260 & 732.9 & 7,850 \\
Pertamax & 44791 & 768.7 & 9,200 \\
LPG & 47089.29 & 1.5 & 17,000 \\
\hline
\end{tabular}

fuel. The measured water volume and the mass of gasoline (Pertalite and Pertamax) and LPG fuel that has used, so that the heating efficiency has calculated by the following formula.

$$
\begin{gathered}
m_{b b}=m_{a}-m_{a k} \\
\dot{m}_{b b}=\frac{m_{b b}}{t}
\end{gathered}
$$

where

$$
\begin{array}{ll}
m_{b b} & =\text { mass of fuel consumed }(\mathrm{kg}) \\
m_{a} & =\text { initial fuel mass }(\mathrm{kg}) \\
m_{a k} & =\text { final fuel mass }(\mathrm{kg}) \\
\dot{m}_{b b} & =\text { fuel mass flow rate }(\mathrm{kg} / \mathrm{s}) \\
t & =\text { boiling time }(\mathrm{s})
\end{array}
$$

Combustion Power $\left(P_{i n}\right)$ is the heat energy contained in the fuel multiplied by the mass flow rate (m) used in the boiling process.

$$
P_{i n}=\dot{m}_{b b} \cdot L H V
$$

where

$$
P_{\text {in }}=\text { net power to raise the water temperature }(\mathrm{kW})
$$$$
L H V=\text { the lowest calorific value of fuel }(\mathrm{kJ} / \mathrm{Kg})
$$

Output power $\left(P_{\text {out }}\right)$ is the ratio of the energy used to heat water to the length of time which it takes to reach its boiling point [16].

$$
P_{\text {out }}=\frac{m_{\text {air }} \cdot c p_{\text {air }} \cdot \Delta T_{\text {air }}+m_{\text {panci }} \cdot c p_{\text {panci }} \cdot \Delta T_{\text {panci }}}{t}
$$

where

$$
\begin{array}{ll}
P_{\text {out }} & =\text { nett power }(\mathrm{kW}) \\
m_{\text {air }} & =\text { water density }(\mathrm{kg}) \\
C p_{\text {air }} & =\text { specific heat of the water }\left(\mathrm{kJ} / \mathrm{kg}{ }^{\circ} \mathrm{C}\right) \\
m_{\text {panci }} & =\text { the mass of pan }(\mathrm{kg}) \\
C p_{\text {panic }} & =\text { specific heat ofpan }\left(\mathrm{kJ} / \mathrm{kg}{ }^{\circ} \mathrm{C}\right) \\
\Delta T & =\text { difference in temperature }\left({ }^{\circ} \mathrm{C}\right)
\end{array}
$$

The heating efficiency $(\eta)$ is ratio between net power that isused to boil water and the combustion power of the fuel.

$$
\eta=\frac{P_{o u t}}{P_{i n}} \times 100 \%
$$

The initial conditions of the study in the form of air density and specifications of other research materials can be seen in Table 2 .

\subsection{Economic value}

The economic value of the use of petroleum fuel types Pertalite and Pertamax and LPG fuel is the number of fuel costs used to boil 1 (one) liter of water. There are two parts economic value such as fix cost likely stove and its installation, and change cost likely consume rate of fuel in the boiling process of a litre of water with the time required in the boiling process. 


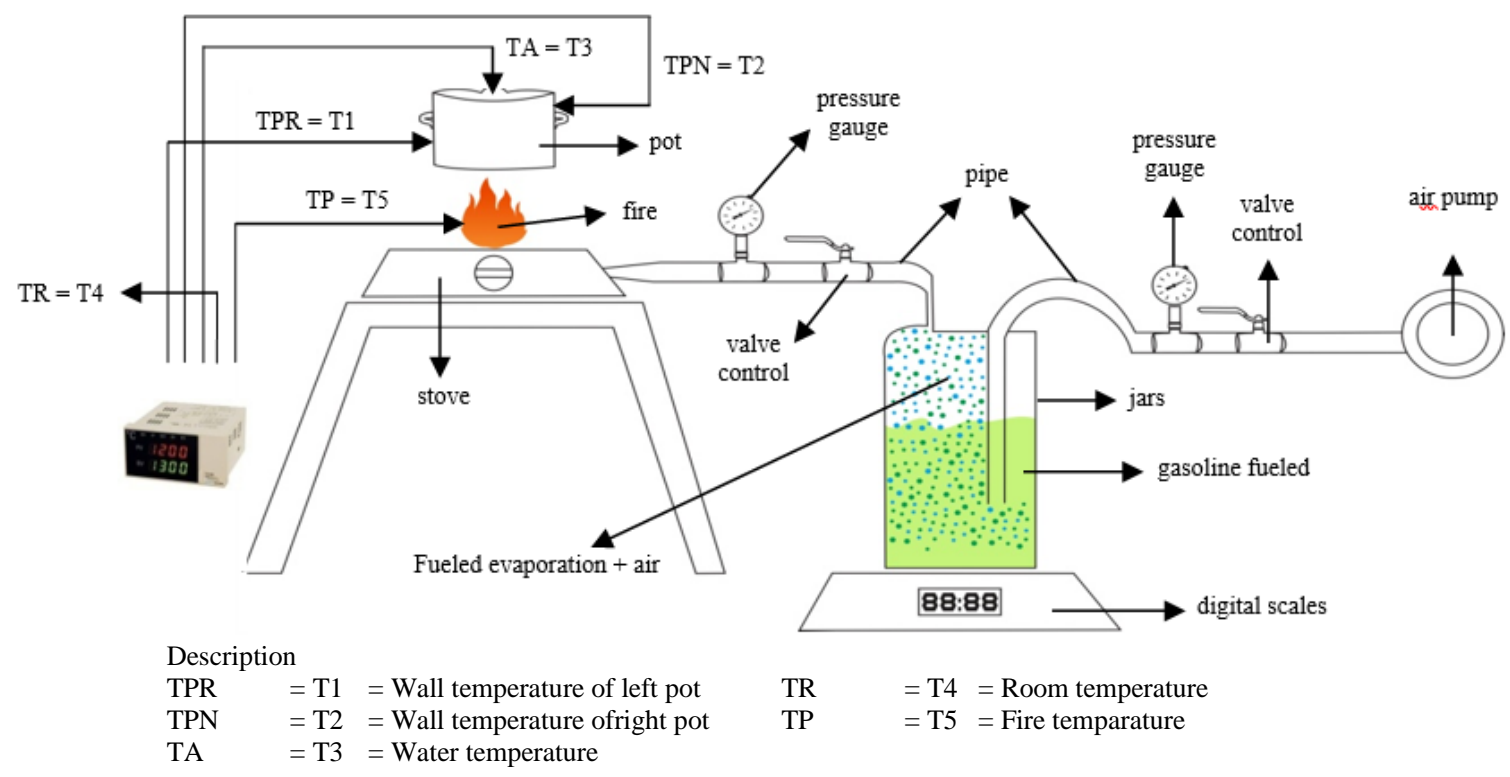

Figure 1. Testing sketch of boiling water

Table 2. Initial condition of research [14], [16], [17]

\begin{tabular}{cc}
\hline Initial Condition & Magnitude \\
\hline Water mass & $0.968 \mathrm{~kg}$ \\
Pan mass & $0.219 \mathrm{~kg}$ \\
$\mathrm{Cp}$ (specific of water) & $4.1866 \mathrm{~kJ} / \mathrm{kg}^{\circ} \mathrm{C}$ \\
$\mathrm{Cp}$ (specific of pan) & $0.9 \mathrm{~kJ} / \mathrm{kg}{ }^{\circ} \mathrm{C}$ \\
Air density $(\rho)$ & $1.2 \mathrm{~kg} / \mathrm{m}^{3}$ \\
\hline
\end{tabular}

$$
B_{b b}=m_{b b} \cdot H_{b b}
$$

where

$B_{b b} \quad=$ fuel cost $(\mathrm{Rp})$

$m_{b b} \quad=$ consume rate of fuel (liter)

$H_{b b} \quad=$ price of fuel $(\mathrm{Rp})$

\section{Research Methodology}

\subsection{Research tools and materials}

- Materials of Research
a. Water
c. Pertalite
b. Pertamax
d. LPG $3 \mathrm{~kg}$

- Tools of Research
a. Termokopel
f. Stove
b. Digital scales
g. Air pump
c. Stopwatch
h. Pot
d. Manometer
i. Jars
e. Measuring glass

\subsection{Testing method}

The testing method has conducted by using one eye stove for boiling a litre of water. Gasoline fuel in the reactor tube pumped with air pump, and at the same time use to vaporize gasoline fuel such as revealed in Fig. 1.

\section{Result and Discussion}

\subsection{Analysis of maturity characteristic}

Testing has conducted on this research so we can analyze the relation of two variables that is pressure and fire temperature (shown in Fig. 2).

Figure 2 has revealed a firing temperature for Pertalite fuel reach out $349{ }^{\circ} \mathrm{C}$ at $1,5 \mathrm{kPa}$ of pressure and reach out the highest temperature at $430{ }^{\circ} \mathrm{C}$ on $2.5 \mathrm{kPa}$ of pressure. For Pertamax fuel, the fire temperature at 1.5 $\mathrm{kPa}$ is $416{ }^{\circ} \mathrm{C}$ and the highest temperature is $530{ }^{\circ} \mathrm{C}$ at $2.5 \mathrm{kPa}$. Meanwhile, for LPG fuel, the firing temperature at $1.5 \mathrm{kPa}$ of pressure is $483{ }^{\circ} \mathrm{C}$, and the highest temperature in $578{ }^{\circ} \mathrm{C}$ at $1.8 \mathrm{kPa}$ of pressure. There were fluctuations at several pressure points up to a pressure of $2.2 \mathrm{kPa}$ to $2.5 \mathrm{kPa}$ for Pertalite and Pertamax fuels, the fire temperature continued to increase.

Figure 3 has reveals the relationship between pressure and consume rate of fuel. Figure 3 has shown that the higher pressure, the lower the fuel consumption. The highest of fuel consumption rate is used LPG fuel. by pressure variation has used among $0.054 \mathrm{~kg}$ to $0.066 \mathrm{~kg}$. Rate fuel consumption pertamax and pertalite fuel is relatively between from $0.021 \mathrm{~kg}$ to $0.033 \mathrm{~kg}$. Figure 4 revealed relationship between pressure and boiling time of water.

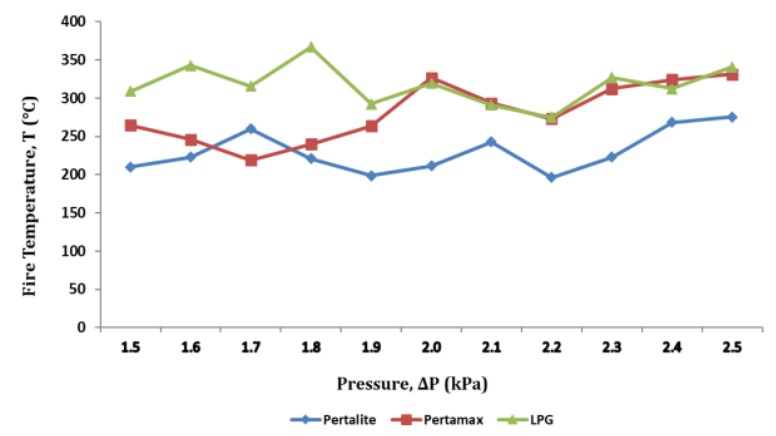

Figure 2. Relation of pressure $(\Delta \mathrm{P})$ to fire temperature $\left({ }^{\circ} \mathrm{C}\right)$ at gasoline fuel (Pertalite, Pertamax) and LPG fuel 


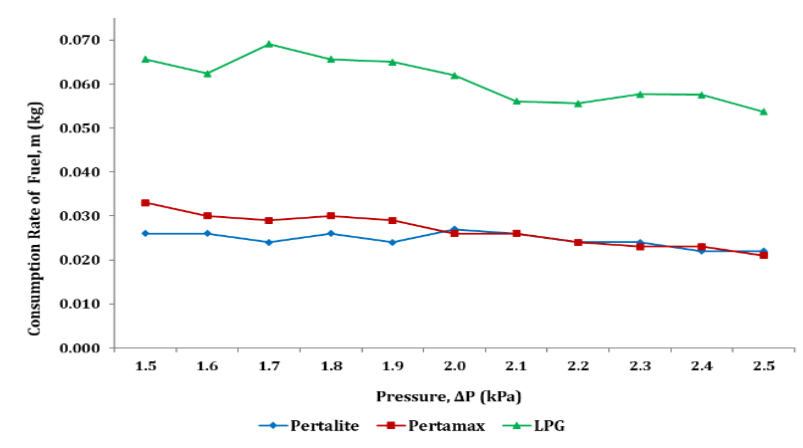

Figure 3. Pressure $(\Delta \mathrm{P})$ to consume rate of fuel the gasoline fuel (Pertalite, Pertamax) and LPG fuel

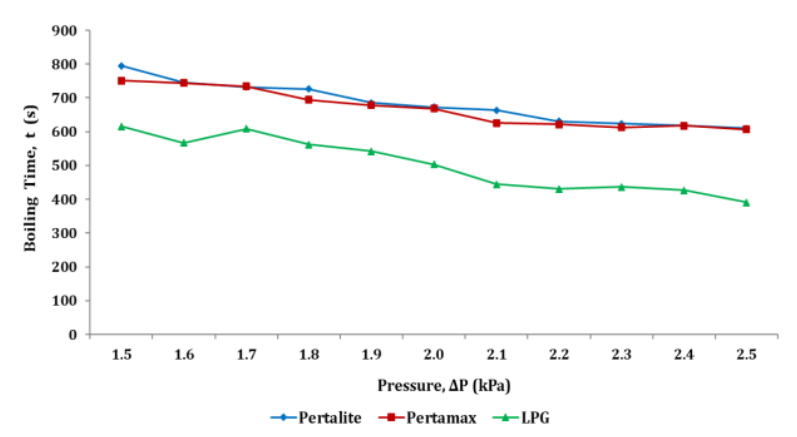

Figure 4. Pressure $(\Delta \mathrm{P})$ with boiling time in the gasoline (Pertalite, Pertamax) and LPG fuels

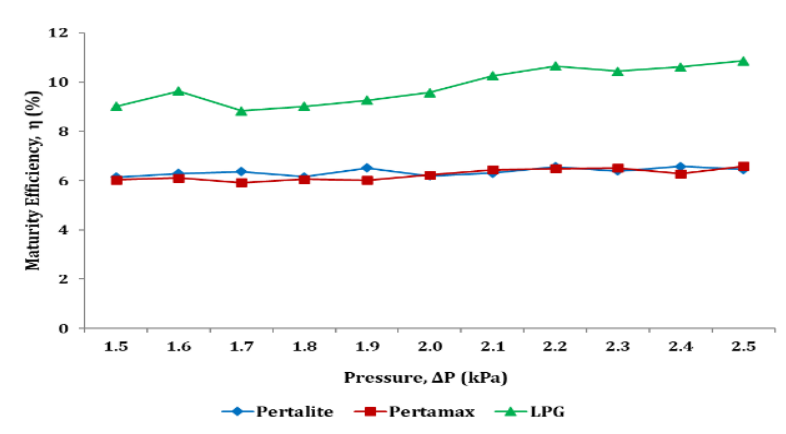

Figure 5. Pressure $(\Delta \mathrm{P})$ to Maturity Efficiency in the gasoline (Pertalite, Pertamax) and LPG fuels

Figure 4 shows that the fastest boiling time has used LPG fuel that its time among 391 seconds to 616 seconds. Pertamax and Pertalite fuel reveal relatively equal in the time and magnitude value that is the higher pressure, the shorter the simmering time required from 607 seconds to 795 seconds.

Figure 5 shows relationship between pressure and maturity Efficiency in the gasoline fuel. Figure 5 reveals that the efficiency value of pertalite and pertamax fuels is relatively constant on ranges between $6.359 \%$ and 8.020 $\%$. For LPG fuel, there is enhance efficiency as long as increased pressure. The highest value of efficiency on 2.5 $\mathrm{kPa}(10.857 \%), 1.5 \mathrm{kPa}(9.018 \%)$. This shows that the greater the pressure applied, the greater the tomaturity efficiency value.

\subsection{Maturity cost analysis}

The cost comparison parameter used is operational costs. For costs of investment are considered relatively the same because they is use the same stove despite using

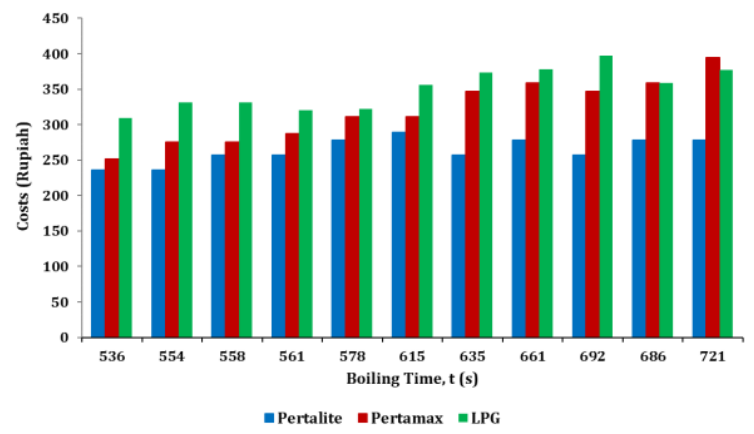

Figure 6. Boiling Time to Cost of Gasoline (Pertalite, Pertamax) and LPG fuels

different fuel containers. Figure 6 shows that greater the time, and greater operational cost. It also appears that the lowest operating costs are pertalite fuel then pertamax and finally LPG.

To boil water 1 litre of water with pertalite fuel at a pressure of $2.5 \mathrm{kPa}$, it costs 236 Rupiah and for pertamax fuel of 251 Rupiah. As for LPG fuel amount to 309 Rupiah. For low pressure (1.5 kPa), it costs 278 Rupiah for Pertalite, 395 Rupiah for Pertamax and 377 Rupiah for LPG.

\section{Conclusion}

The highest fire temperatures for Pertalite fuel are $430{ }^{\circ} \mathrm{C}$, Pertamax fuel $530{ }^{\circ} \mathrm{C}$ fuel and LPG $578{ }^{\circ} \mathrm{C}$ fuel. Fuel consumption at $2.5 \mathrm{kPa}$ for Pertamax $0,021 \mathrm{~kg}$ fuel, Pertalite fuel $0.022 \mathrm{~kg}$, and LPG fuel $0.054 \mathrm{~kg}$. For the fastest discharge time occurs at a pressure of $2.5 \mathrm{kPa}$, for LPG fuel takes 391 seconds, Pertamax 607 seconds fuel and Pertalite fuel time is 610 seconds. While the fuel efficiency value at $2.5 \mathrm{kPa}$ has obtained for Pertalite fuel is $6.136 \%$, Pertamax fuel, $7.730 \%$ and LPG fuel $9.018 \%$. The cost required to boil 1 (one) litre of water is Pertalite fuel amounting to Rp. 236,- Pertamax fuel Rp. 257,- and LPG fuel of Rp. 309,-. This research should be a reference for household users to overcome the scarcity of LPG.

\section{References}

[1] Ahmad Hidajat Effendi, "Fire Safe and Energy Saving Stove Performance Study (AHE Stove)," Settlement Journal, vol. 3, no. 1, May 2008.

[2] Diah Krisnatuti Pranadji, Muhammad Djemdjem Djamaludin, Nuriza Kiftiah, "Behavior Analysis of Household Use of LPG in Bogor City," vol. 3, no. 2, p. 173 - 183, ISSN : 1907 - 6037, August 2010.

[3] Nur Ikhwani, "Community Acceptance of the Use of LPG Gas in Dusun Tua Village, Kelayang District, Indragiri Hulu Regency," JOM FISIP, vol. 6, Riau University, 2019.

[4] Bayu Maidi Alkarim, R. Hengki Rahmanto, M. Irham Mahfud, "Effect of Air Pressure on Gasoline Stoves on Combustion Performance with the Evaporation Method," Mechanical Engineering Scientific Journal, vol. 6, no. 2, August 2018, Islamic University 45 Bekasi.

[5] Kemas Ridhuan and Ervan Septa Darma, "Variations in The Number of Holes and The Size of The Burner Diameter of The Premium Stove on Fuel Consumption," Journal of Mechanical Engineering, Muhammadiyah Metro University, vol. 5, no. 2, p ISSN : 2301 - 6663, e - ISSN : 2477 - 250 X, 2016.

[6] Sukardi and Hilda Porawati, "Reactor Tube Design on Used Canned Fuel Stove," Journal of Innovators, vol. 2, no. 2, 2019.

[7] Rayyan, Abdul Wahab, Margianto, "Comparison of the use of Pertalite and Pertamax Turbo fuels against carbon residue and performance on 2013 Yamaha Byson motorbikes". 
[8] P. Nara Wiryawan, G. Widayana, Rihendra Dantes, "The Comparative Effect of Using Pertalite Oil and LPG Fuel on The Performance of a 4-Stroke Gasoline Motorbike on a Honda Supra Fit," Journal of The Department of Mechanical Engineering Education, vol. 8, no. 2, Ganesha University of Education, 2017.

[9] Tri Susilo Wirawan, Ikram Anugrah, Suryanto, Musrady Mulyadi, "Analysis of Gasoline Fuel on the Performance and Economic Value of the CM 11 Gasoline Motor," Proceedings of the Research Results Seminar (SNP2M), pp. 12 - 17, 978-602-60766-4-9, 2018.

[10] Joko Triyatno, "Comparison of the Use of Natural Gas to LPG in Meeting Household Needs in Bontang," Al Ulum Science and Technology, vol. 4, no. 1, STTIB Bontang, November 2018.

[11] Wahyudi, "Research of Calorific Value of Biomass: Comparison of Test Results and Calculation Results," Semesta Teknika Scientific Journal, vol. 9, no. 2, 2006.

[12]Dian Marya Novita and Enri Damanhuri, "Calculation of Heating Value Based on The Composition and Characteristics of Urban Waste in Indonesia in The Concept of Waste to Energy," Journal of Environmental Engineering, vol. 16, no. 2, October 2010.
[13]Dwi Yuliyanto and Edi Widodo, "Effect Against Fuel type viscosity and TBN Lubricant SAE $10 \mathrm{~W}$ - 30 On Motor Fuel 125 cc," Manufacturing Energy Engineering Journal, vol. 3, no. 1, 2018.

[14]Agung Sugeng Widodo," Increased Heating System Efficiency with The Addition Of A Grid To A Pertorated Burner" Journal of Mechanical Engineering, vol. 7, no. 1, ISSN 2477 - 6041, 21 - 25, 2016.

[15] Sudarno and Fadelan, "Increasing the Efficiency of the LPG Stove Using the Fire Element," Semesta Teknika Scientific Journal, vol. 19, no. 2, November 2016.

[16] Arif Mulyanto, Mirmanto, Muhammad Athar, "Effect of Height of Air inlets of Biomass Combustion Furnaces on Performance," Mechanical Engineering Dynamics, vol. 6, no. 1, June 2016, p. ISSN: 2088 - 088X, e. ISSN : 2502 - 1729.

[17] Maula Nafi, "Hardness Analysis of AL - 6061 COR Results with Double Quenching Heat Treatment," Mechanics - Journal of Mechanical Engineering, vol. 2, no. 2, 2016. 